\title{
In vitro propagation of some tomato (Lycopersicon esculentum Mill.) hybrids
}

$* \quad *$

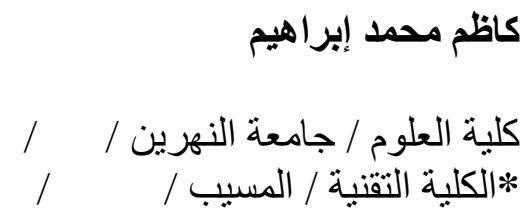

Rola Speedy Nirita Ginan بذور اربعة هجن من الطماطة وهي

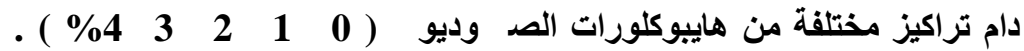

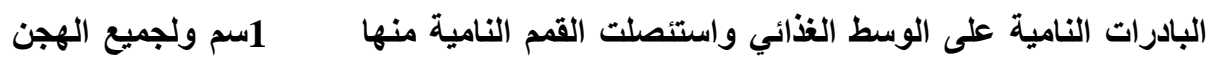

Eذائية جديدة زودت بتراكيز مختلفة من منظمات النمو (Indole acetic acid (IAA) Benzyl adenine (BA) بهذف الحصول على افضل وسط للتضاعف الخضري ـ اجريت تجربة اخرى لاستحثاث الكالس من زراعة السويقة الجنينية السفلى لهجن الطماطة الاربعة على وسط غذائي مزود بتراكيز مختلفة من BA 1000

ـ اظهرت النتائج تفوق التركيز NaOCl \%4 في تعقيم بذور الهجن والحصول على بادرات خالية من

$$
\text { ، وبينت النتائج تفوق التركيز } 2 \text { / / }
$$

خضري للهجن الاربعة من BA / تفوق هذا التركيز معنوياً في معدل الوزن الطري والجاف للكالس مقارنة ببقية المعاملات .

\section{Abstract}

Seeds of four tomato hybrids Ginan, Nirtia, Speedy and Rola were cultured on aseptic germination medium after surface sterilization with $\mathrm{NaOCl}$. Shoot tips $1 \mathrm{~cm}$ length were dissected and grown on MS medium supplemented with Benzyl adenine (BA) and Indole acetic acid (IAA) for multiplication. Callus was induced on hypocotyls cultured on MS medium supplemented with BA under light intensity of 1000 lux and $25{ }^{0} \mathrm{C}$. Results showed that $\mathrm{NaOCl}$ at $4 \%$ completely disinfected seeds and resulted in pathogen free seedlings.

Results also showed that a concentration of $4 \mathrm{mg} / \mathrm{l}$ of $\mathrm{BA}$ was superior in increasing callus fresh and dry weights. Shoot multiplication was achieved on the same medium supplemented with 2 and $0.8 \mathrm{mg} / \mathrm{l}$ of BA and IAA respectively. 
للحفاظ على صفات النوع من التدهور

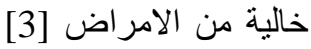

[4] ان افضل تضاعف تم الحصول عليه عند زراعة

Fantastic القمم النامية للصنف

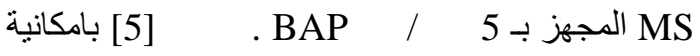

اكثار هجن الطماطة باستعمال القمم النامية للبادرات

[6]

الحصول عليها عند زراعة القمم النامية لهجن الطماطة.

الهجينة قلد استهدف هذا البحث اكثار الهجن بواسطة تقنية زراعة الانسجة باستخدام القمم النامية وتحديد التركيز المناسب للتضاعف الخضري بهدف انتاج شتلات من هجن الجيل الاول دون الحاجة الى استير ادها

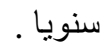

MS

بالفيتامينات و السكروز بتر اكيز مختلفة من منظم النمو

/ $\quad 2.0 \quad 1.5 \quad 1.0 \quad 0.5 \quad 0.0 \quad$ وهي BA بالتداخل مع تر اكيز مختلفة من منظم النمو IAA وهي

$$
\begin{array}{lllll}
/ & 0.8 & 0.4 & 0.2 & 0.0
\end{array}
$$

1000

$$
{ }^{\circ} 1 \pm 25
$$

$$
16 \text { ساعة/ يوم . }
$$

$$
\text { الافرع و اطو الها بعد اربعة اسابيع من الزراعة. }
$$

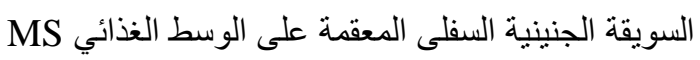

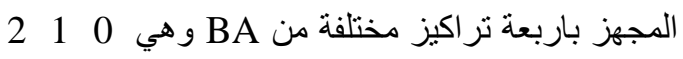
4

$$
\begin{aligned}
& 1 \pm 25 \\
& 1000 \\
& \text { لفترة خمسة اسابيع واخذت القياسات على الزروعات }
\end{aligned}
$$

\begin{abstract}
مهما
لقيمتها الغذائية العالية ولاستعمالاتها المتنوعة تزرع الاصناف الهجينة ذات الصفات الجيدة من حيث

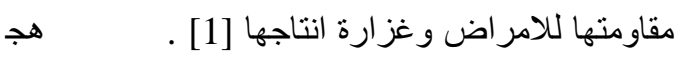
هذه الاصناف مستوردة وتباع بالعما باهضة الثمن من قبل شركات عالمية متخصصة. البحث عن امكانية اكثار تللك الاصناف الهجينة بطرق غير تقيلدية لاتعتمد عل البذرة يمكن ان يوفر مبالغ طائلة استير اد بذور تلك الاصناف . على هذا

الاساس جاءت فكرة هذا البحث باكثار الا ل لعجينة باستخدام تقنية زراعة الانسجة والتي تعني عزل نسيج

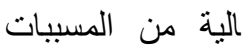

المرضية وتعقيمه وزراعته اوساط غذائية معقمة مسيطر عليها من حيث الحرارة والضوء [2] . ية للبادرات المعقمة
\end{abstract}

$$
\begin{aligned}
& \text { اربعة هجن } \\
& \text { و هي جنان ، ناريتا ، سبيدي }
\end{aligned}
$$

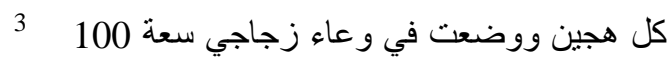

$$
\begin{aligned}
& \text { اضيف لها الكحول الاثيلي }
\end{aligned}
$$

\section{[7] ( MS)}

$$
14 \text { يوم وبطول } 4
$$

1 Shoot tips 
التحليل الاحصائي

Randomized Design (CRD) .[8] 0.05

(LSD)
الييانـات الخاصـة بالتجـارب المختبريـة والتجـارب

الحقليـة احصــائبا بوصـفهـا تجــارب عامليـة باســتخدام

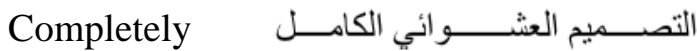

\section{تعقيم بذور الهجن}

يبين جدول (1) ناثير هاييوكلورات الصـوديوم في الحد بـ من تلوث بذور الهجن ، فقد بلغت نسبة التلوث 100\% في جميع الهجن عنــ معاملـة المقارنـة (بـدون استخدام هايبوكلور ات الصـوديوم) ـو انخفضت نسبة النلوث مـع زيـادة نسبة تركيز المـادة المعقمـة يلاحظ عند زيسادة لهجينين

تركيز NaOCl بينما كانت ناريتا وروولا بلغت $10 \quad$ 20\%

(1) : تاثير هايبوكلورات الصوديوم تعقيم بذورهن الطماطة

\begin{tabular}{|c|c|c|c|c|}
\hline \multicolumn{4}{|c|}{ \% لتلوث الهجن } & \multirow[t]{2}{*}{ الهجن } \\
\hline & سبيدي & 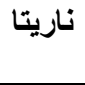 & & \\
\hline 100 & 100 & 100 & 100 & 0 \\
\hline 80 & 70 & 80 & 70 & 1 \\
\hline 60 & 30 & 50 & 40 & 2 \\
\hline 20 & 0 & 10 & 0 & 3 \\
\hline 0 & 0 & 0 & 0 & 4 \\
\hline
\end{tabular}

وتبين النتائج في الثكل (1 ج) وجود فروق معنويـة بين الهجن في معدل عدد الافرع اعطى الهجين 0.92

الهجين سبيدي اقل عدد من الافرع بلغ 0.67 ونتشير النتائج في الجدول (2) ان التـاخل الثلاثي بين IAA BA اعطى الهجين جنـان اعلى معدل للافرع في الوسط

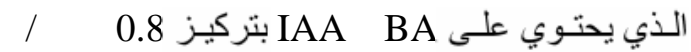

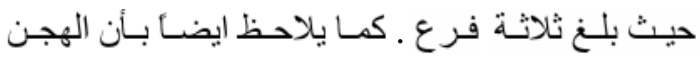

1. تاثير تركيز كل من IAA BA و الهجين في عدد تثبر النتائج في الثكل (1 أ) بـان عدد الافرع ا معنويأ مع زيادة تركيز BA المقارنـة. واظهرت

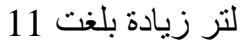
IAA تاثير أ معنويـاً على معدل عدد الافرع، | سلكت النتائج : مشـابهاً لتاثير BA و اعطى التركيز 0.8 ملغم / لتر اعلى معدل معاملة المقارنة. $3.5: 1 .: 11 \quad \ddot{x}$ i. -11.1 
و النــايتوكانينات فـي انقســام الخلايــا النباتيــة ونموهــا

وتمايز ها وقد يرجع اختلاف استجابة الهجن لمستويات

لها في الوسط الخالي من IAA BA .

الى التباين في تركيبها الور اثي و هذا ينفق IAA BA

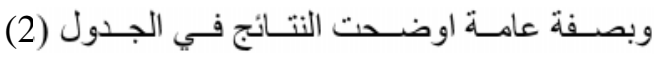

. $[11,10,6]$

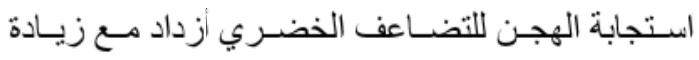

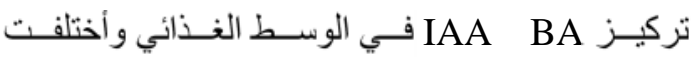

بـاختلاف الهجن قد يعزى ذلك الـى دور الاوكسينات
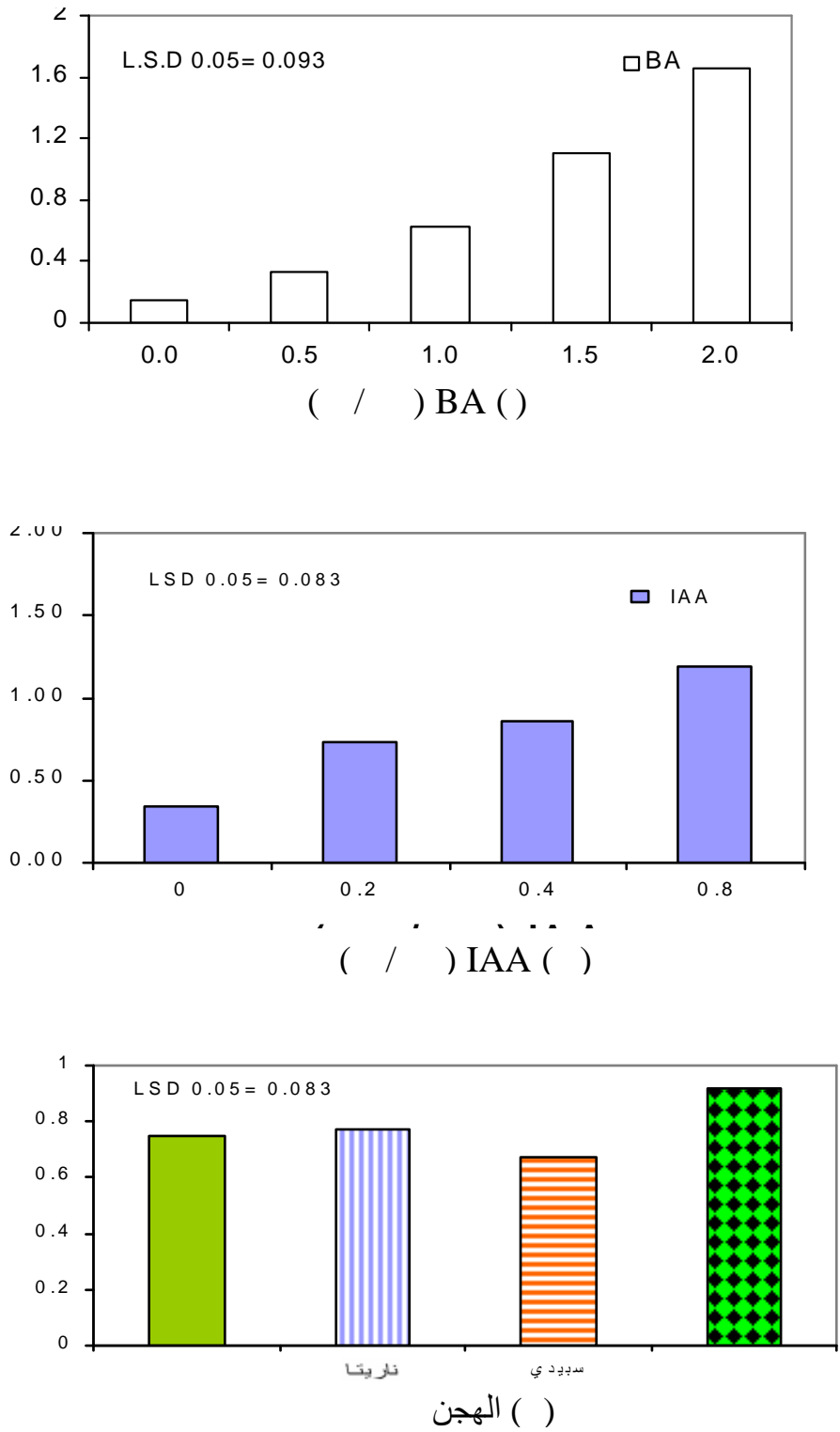

(1) : تاثير تركيز IAA BA (ملفم/ لتر) و الهجي

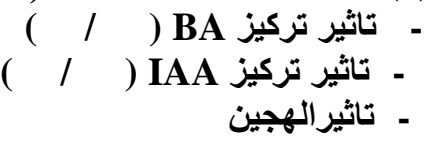




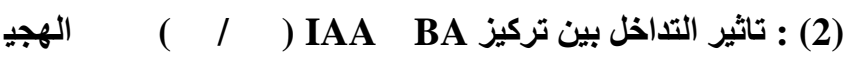

\begin{tabular}{|c|c|c|c|c|c|}
\hline & سبيدي & ناريتا & & $\mathbf{B A}$ & IAA \\
\hline 0.0 & 0.0 & 0.0 & 0.0 & 0.0 & \multirow{5}{*}{0.0} \\
\hline 0.1 & 0.1 & 0.1 & 0.1 & 0.5 & \\
\hline 0.4 & 0.5 & 0.2 & 0.3 & 1.0 & \\
\hline 0.5 & 0.6 & 0.5 & 0.5 & 1.5 & \\
\hline 0.9 & 0.6 & 0.8 & 0.6 & 2.0 & \\
\hline 0.4 & 0.4 & 0.2 & 0.1 & 0.0 & \multirow{5}{*}{0.2} \\
\hline 0.5 & 0.3 & 0.4 & 0.3 & 0.5 & \\
\hline 0.8 & 0.4 & 0.5 & 0.4 & 1.0 & \\
\hline 1.2 & 0.9 & 0.9 & 1.1 & 1.5 & \\
\hline 1.7 & 1.2 & 1.3 & 1.5 & 2.0 & \\
\hline 0.2 & 0.1 & 0.1 & 0.1 & 0.0 & \multirow{5}{*}{0.4} \\
\hline 0.6 & 0.4 & 0.2 & 0.4 & 0.5 & \\
\hline 1.1 & 0.8 & 0.4 & 0.8 & 1.0 & \\
\hline 1.6 & 0.9 & 1.2 & 1.2 & 1.5 & \\
\hline 2.1 & 1.5 & 1.5 & 1.9 & 2.0 & \\
\hline 0.1 & 0.2 & 0.4 & 0.2 & 0.0 & \multirow{5}{*}{0.8} \\
\hline 0.6 & 0.4 & 0.5 & 0.4 & 0.5 & \\
\hline 1.0 & 0.5 & 1.0 & 0.9 & 1.0 & \\
\hline 2.0 & 1.1 & 2.4 & 1.2 & 1.5 & \\
\hline 2.7 & 2.6 & 2.8 & 3.0 & 2.0 & \\
\hline \multicolumn{5}{|c|}{0.374} & $\begin{array}{l}\text { LSD } \\
0.05\end{array}$ \\
\hline
\end{tabular}

\section{تاثير كل من تركيز IAA BA}

و واظهرت البيانات في الثكل (2 ج) ان استجابة الهجن

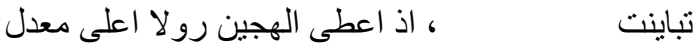

BA 2) (2)

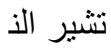

لهذه الصفة بلغ 1.99 بينما اظهر الهجين سبيدي

/ 0.5 التركيز 0.5

2.73 سم ولم يختلف معنوياً عن

1.71

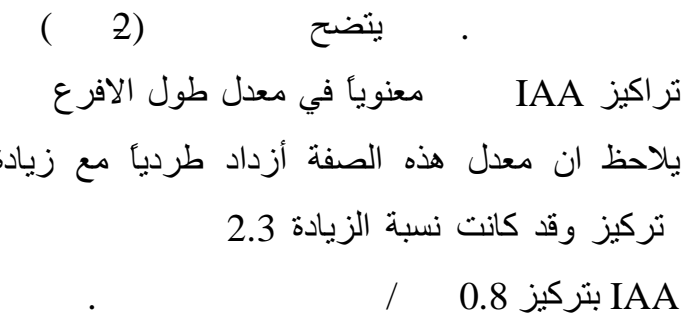



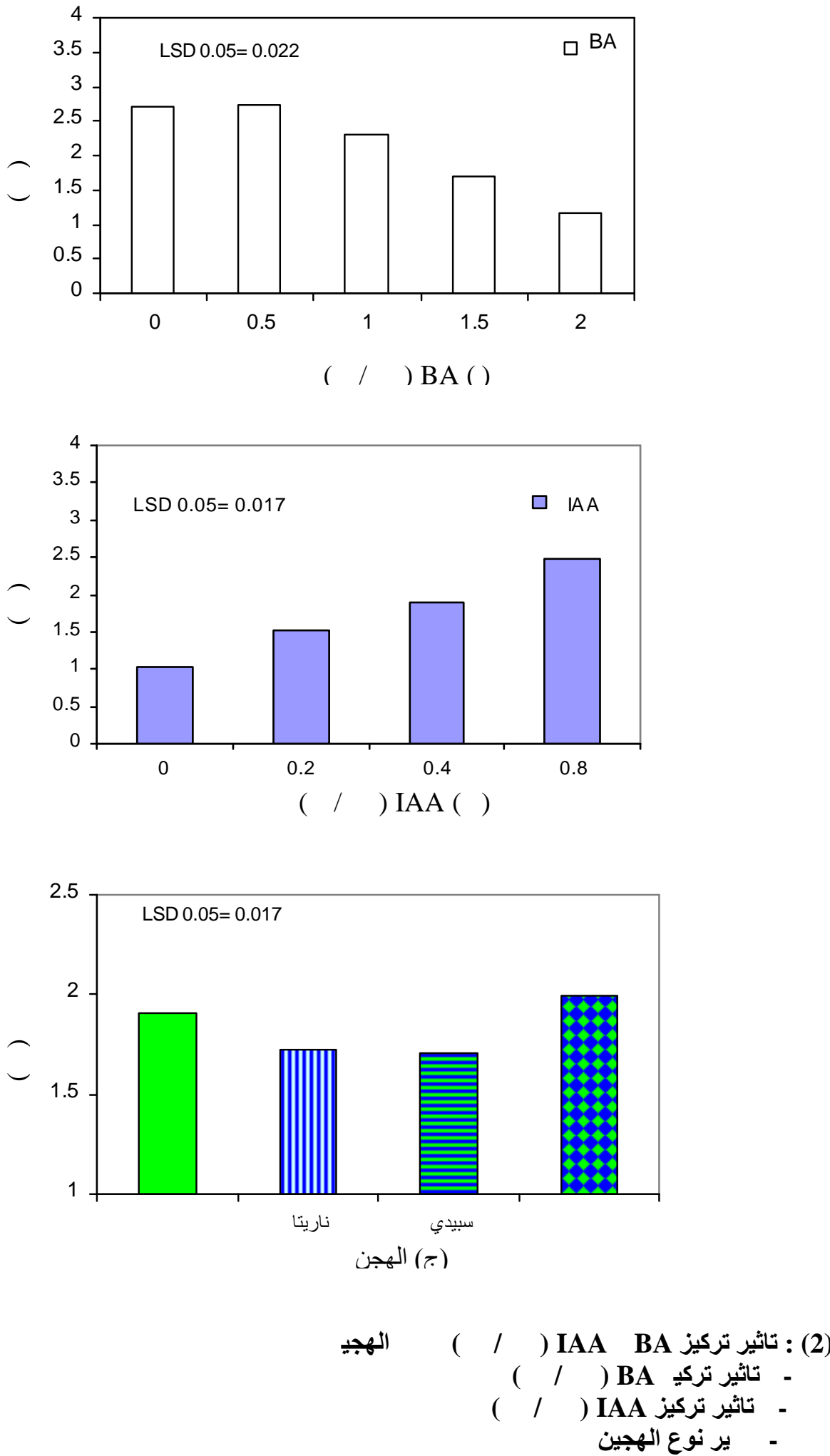

$3.80 \quad$ ل لهذه

BA وتشير النتـائج في الجدول (3) بـان التداخل الثلاثـي بين جن معنويأ في معدل طول 
وقد يعود ذلك الـى دور الاوكسينات في استطالة الخلايـا النباتية ان زيـادة تركيز هـا سبب تلك الاستطالة ضـمن مدى معين تبعأ لاختلاف الانسجة و عمر هـا الفسيولوجي . و هذه النتائج تتفق مع نتائج الباحثين [12 12 13 ـ
الهجين رو لا في حين بلغ اقل طو $\quad 0.73$ اضـافة IAA وبوجـود BA بتركيز 2.0 ملغم/ لتـر مـع

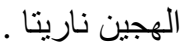

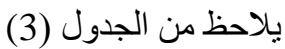

BA تركيز IAA مع زيادة تركيز الوسط الغذائي وقد اختلفت الاستجابة بـاختلاف الهجن .

(3) : تاثير التداخل بين مستويات IAA BA

\begin{tabular}{|c|c|c|c|c|c|}
\hline & سبيدي & ناريتا & & BA & IAA \\
\hline 0.0 & 0.0 & 0.0 & 0.0 & 0.0 & \multirow{5}{*}{0.0} \\
\hline 1.90 & 1.70 & 1.65 & 1.85 & 0.5 & \\
\hline 1.55 & 1.37 & 1.32 & 1.51 & 1.0 & \\
\hline 1.26 & 1.04 & 1.15 & 1.23 & 1.5 & \\
\hline 0.85 & 0.76 & 0.73 & 0.84 & 2.0 & \\
\hline 3.00 & 2.70 & 2.77 & 2.95 & 0.0 & \multirow{5}{*}{0.2} \\
\hline 2.26 & 2.00 & 2.30 & 2.25 & 0.5 & \\
\hline 2.45 & 1.97 & 2.17 & 2.42 & 1.0 & \\
\hline 1.44 & 1.15 & 1.19 & 1.41 & 1.5 & \\
\hline 1.00 & 0.94 & 0.86 & 1.09 & 2.0 & \\
\hline 3.45 & 3.10 & 3.20 & 3.40 & 0.0 & \multirow{5}{*}{0.4} \\
\hline 2.91 & 2.58 & 2.75 & 2.88 & 0.5 & \\
\hline 2.45 & 1.97 & 2.17 & 2.42 & 1.0 & \\
\hline 1.91 & 1.56 & 1.67 & 1.86 & 1.5 & \\
\hline 1.37 & 1.01 & 1.14 & 1.31 & 2.0 & \\
\hline 3.80 & 3.35 & 3.32 & 3.55 & 0.0 & \multirow{5}{*}{0.8} \\
\hline 3.53 & 3.15 & 3.02 & 3.32 & 0.5 & \\
\hline 3.18 & 2.80 & 2.76 & 3.13 & 1.0 & \\
\hline 2.41 & 2.40 & 2.13 & 2.33 & 1.5 & \\
\hline 1.62 & 2.00 & 1.30 & 1.59 & 2.0 & \\
\hline \multicolumn{5}{|c|}{0.105} & LSD 0.05 \\
\hline
\end{tabular}

وزن للكـالس 19.83 ملغـم عنــد اضـافة BA بتركيـز 1

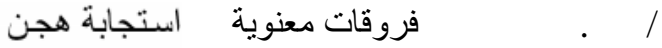
الطماطة الاربعة لتكوين الكالس، ا اعطى الهجين جنـان

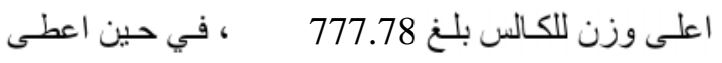
الهجين ناريتا اقل وزن للكالس بلغ 520.53

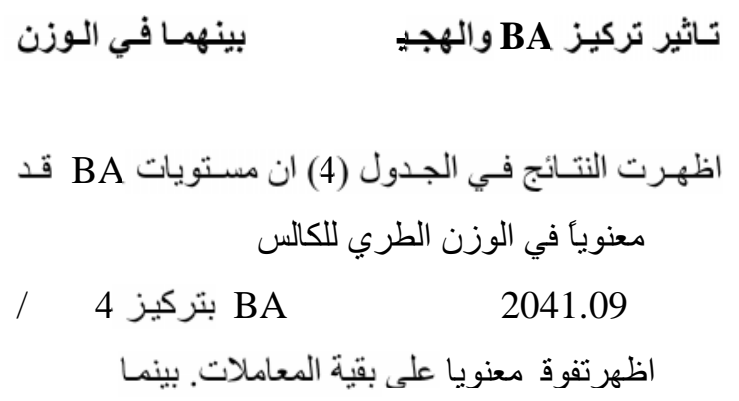

ت تاثير تركيز BA

اظهرتفوق معنويا على بقية المعاملات. بينما 


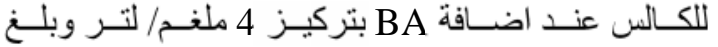

2512.96

/ بتركيز 1.0 BA

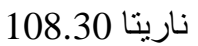

ويلاحظ من الجدول (4) ايضـاوجود تداخل معنوي بين مستويات BA و الهجن في معدل الوزن الطري للكالس، فقد اظهرت جميع الهجن تفوقأ في معدل وزن الكالس مـع إنع

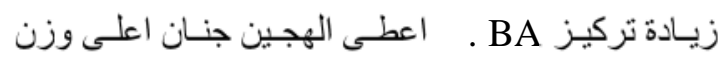

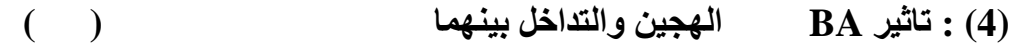

\begin{tabular}{|c|c|c|c|c|c|}
\hline $\mathbf{B A}$ & & سبيدي - & 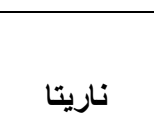 & & /الهجن \\
\hline 0 & 0 & 0 & 0 & 0 & \\
\hline 119.83 & 109.16 & 126.80 & 108.30 & 135.08 & 1.0 \\
\hline 400.05 & 419.62 & 401.88 & 315.60 & 463.08 & 2.0 \\
\hline 2041.09 & 1806.84 & 2186.34 & 1658.22 & 2512.96 & 4.0 \\
\hline $\begin{array}{l}\text { LSD } \\
\text { (BA) }\end{array}$ & \multicolumn{4}{|c|}{52.097} & LSD 0.05 \\
\hline \multirow[t]{2}{*}{26.04} & 583.90 & 678.0 & 520.53 & 777.78 & معدل الهجن \\
\hline & \multicolumn{4}{|c|}{26.04} & LSD للهجن LSD \\
\hline
\end{tabular}

تاثير الـ BA BA بتركيز 1 ملغم/ لتر في الهجين

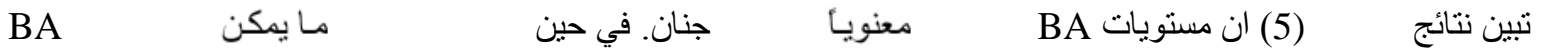
في الـوزن الجـاف للكـالس، حيث يلاحظ ان معدل هذهن

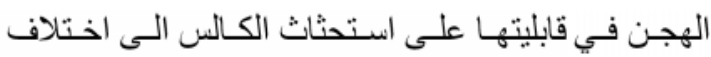

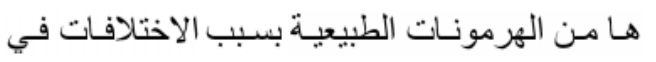
التر اكيب الور اثية لهذه الهجن ـ وهذا يتفق مـع مـاوجده

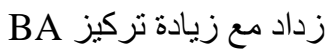

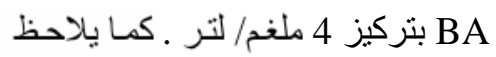

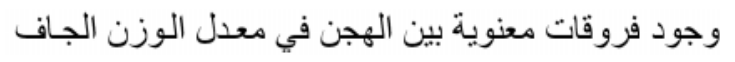

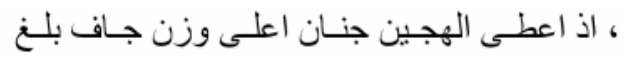
61.05 ملغم. في حين اعطى الهجين ناريتا اقل وزن جاف BA 409.2

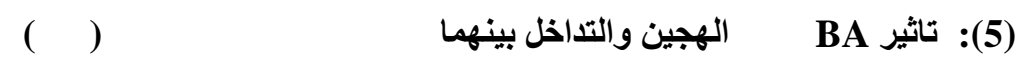

\begin{tabular}{|c|c|c|c|c|c|}
\hline $\mathbf{B A}$ & & سبيدي & ناريتا & & الهجن \\
\hline 0.0 & 0.0 & 0.0 & 0.0 & 0.0 & 0.0 \\
\hline 15.03 & 13.76 & 15.62 & 13.66 & 17.08 & 1.0 \\
\hline 53.67 & 56.46 & 54.12 & 41.64 & 62.46 & 2.0 \\
\hline 133.51 & 118.04 & 142.94 & 108.40 & 164.68 & 4.0 \\
\hline \multirow{3}{*}{$\begin{array}{l}\text { LSD } \\
\text { (BA) } \\
1.856\end{array}$} & \multicolumn{4}{|c|}{3.712} & LSD 0.05 \\
\hline & 47.06 & 53.17 & 40.92 & 61.05 & معدل الهجن \\
\hline & \multicolumn{4}{|c|}{1.86} & \\
\hline
\end{tabular}


Agriculture and Forestry.Vol.2. Crops I.

Springer- $\quad$ Verlag, Berlin

Heidelberg.pp.318-344.

10. Skoog, F. and C.O. Miller. 1957.

Chemical control of growth and bud formation in tobacco segments and callus cultured in vitro. J. Bot. 35: 782 790.

11. Shamshad, G .M., Ahmed, C. M. S. and M. Tahir. 1999. In vitro shoot regeneration of tomato through stem and leaf explants. Pakistan, Journal of Arid Agriculture. Vol. 2 (1): 7-14.

12. Branca, C., Bucci, G., Domiano, P., Ricci, A., Torelli, A. and M. Bassi. 1991. Auxin structure and activity on tomato morphogenesis in vitro and pea stem elongation. Plant-Cell-Tissue and Organ Culture. 24 (2):105-114.

13. الصــالحي، علـي عبــــ الاميـر مهـدي. 1994.

Solanum استجابة سـبعة اصـناف مـن البطاطـا

tuberosum L. للزر اعة النسيجية. رسالة ماجستير

$$
\text { . }
$$

14. Abo-Shady, A., Ghanem, S.A., ELBahr, M.K., Osman, M.E. and M.M.Saker. 1993. Callus induction and plant regeneration from calli of different explants of tomato. Egypt. J. Hort. 20 (2): 355- 371.

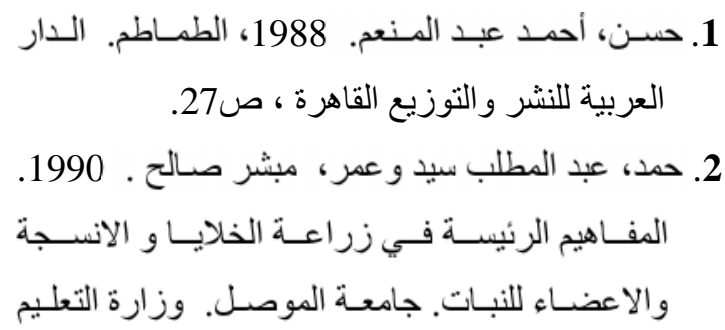

3. Dodds, J. H. and L. W. Roberts.1995. Experiments in Plant Tissue Culture. 3rd.ed. Cambridge Univ. Press. p 111.

4. Schnapp, S. R. and P. J. E. Preece 1986. In Vitro growth reduction of tomato and carnation microplants. Plant Cell, Tissue, Organ culture. 6:3-8.

5. Locy, R. 1998. Plant Biology Laboratory/ tissue culture laboratory manual. www.auburn.edu/ loc rob/teaching /lab.manua11/tiscul.

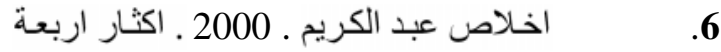
هجن من الطماطة باستخدام تقنية زر اعة الانسجة . رسـالة ماجستير. قسم البستنة. كلية الزراعـة. جامعة

7. Murashige, T and F.Skoog. (1962).

A revised medium for rapid growth and bioassays with tobacco tissue culture.

Physiol.Plant. 15: 473-497.

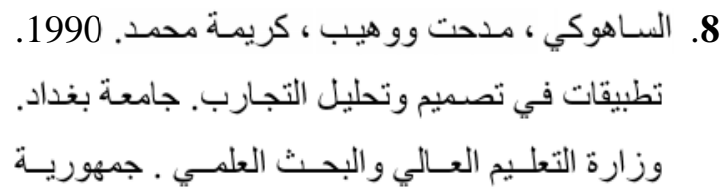

9. Sink, K. and J.Reynolds.1986. Tomato (Lycoperscon esculentum Mill.)In: Bajaj. Y.P.S. (Ed): Biotechnology in 